\title{
SHALLOW SUBLITTORAL BENTHIC COMMUNITIES OF THE LAGUNA ESTUARINE SYSTEM, SOUTH BRAZIL
}

\author{
Gustavo Fonseca \& Sérgio A. Netto* \\ Universidade do Sul de Santa Catarina \\ Laboratório de Ciências Marinhas \\ (Av. Colombo Sales, 84, 88790-000 Laguna, SC, Brasil) \\ *netto@unisul.br
}

A b S T R A C T

Sediment properties, microphytobenthos biomass (chlorophyll $a$ and phaeopigments), and the structure of the benthic communities of the three main lagoons (Mirim, Imaruí and Santo Antonio) of the Laguna Estuarine System, South Brazil, were analyzed during summer and winter. Microphytobenthos biomass did not differ significantly among the lagoons, but showed higher values in the summer. The macrofauna was characterized by low species richness and the dominance of the gastropod Heleobia australis, the tanaidean Kalliapseudes schubartti and the bivalve Erodona mactroides. The meiofauna was composed of 20 higher taxa and the nematodes dominated in all the lagoons and periods. Desmodora (Desmodora) sp.1, Terschllingia sp. and Microlaimus sp. were numerically the most important among the 74 nematode species registered. This study showed that, in the Laguna Estuarine System, differences in the benthos among lagoons and periods were dependent on the fauna component analyzed. Whilst macrofauna and nematodes were significantly more diverse in the inner stations, in the Mirim Lagoon, the number of meiofauna taxa did not differ significantly among the lagoons and the diversity and evenness were highest in Santo Antonio. These results were a response of the fauna to the salinity oscillations coupled with the heterogeneity of the sediment in the lagoons. The temporal variability of the fauna, macrofauna being more abundant in the summer and meiofauna in the winter, could be related to the different life strategies of these groups.

\section{RESUMO}

Propriedades do sedimento, biomassa microfitobêntica (clorofila $a$ e feopigmentos), e a estrutura das comunidades bênticas das três principais lagoas (Mirim, Imaruí e Santo Antonio) do Sistema Estuarino de Laguna, sul do Brasil, foram analisadas durante o verão e inverno. A biomassa microfitobêntica não diferiu significativamente entre as lagoas, mas seus valores foram maiores no verão. A macrofauna foi caracterizada pela baixa riqueza específica e a dominância do gastrópode Heleobia australis, do tanaidáceo Kalliapseudes schubartti e do bivalve Erodona mactroides. A meiofauna foi composta por 20 grupos taxonômicos e os nemátodas dominaram todas as lagoas e períodos. Desmodora (Desmodora) sp.1, Terschllingia sp. e Microlaimus sp. foram numericamente as mais importantes entre as 74 espécies de nemátodas registradas. Este estudo mostrou que, no Sistema Estuarino de Laguna, as diferenças no bentos entre as lagoas e períodos foram dependentes do componente faunístico analisado. Enquanto macrofauna e nemátodas foram significativamente mais diversos nas áreas interiores, na Lagoa Mirim, o número de taxa da meiofauna não diferiu significativamente entre as lagoas e a diversidade e equitatividade foram maiores em Santo Antonio. Estes resultados foram uma resposta da fauna às variações de salinidade e da heterogeneidade do sedimento das lagoas. A variabilidade temporal da fauna, sendo a macrofauna mais abundante no verão e a meiofauna no inverno, pode estar relacionada as diferentes estratégias de vida destes grupos.

Descriptors: Microphytobenthos, Meiofauna, Macrofauna, Nematodes, Laguna Estuarine System, Brazil.

Descritores: Microfitobentos, Meiofauna, Macrofauna, Nematoda, Sistema Estuarino de Laguna, Brasil.

\section{$\mathrm{I}_{\text {NTRODUCTION }}$}

The abundance and/or biomass of different benthic size groups vary considerably by virtue of environmental constraints (Koop \& Griffiths, 1982).
The structure of benthic assemblages and the dynamics of each component of the benthos (i.e. microphytobenthos, meiofauna and macrofauna) may also differ depending on the environmental conditions and trophic state (Danovaro et al., 2000). In the same 
way, it is already known that the meiofauna and macrofauna have different life strategies and mechanisms for the maintenance of the diversity (Warwick, 1984). However, the study of marine benthic communities has traditionally been conducted independently, focusing only one or other of their components. A view showing the relative importance of different components of the benthos from a single sampling campaign is scarce for most marine environments (Koop \& Griffiths, 1982; Albertelli et al., 1999; Netto \& Gallucci, 2003; Gallucci \& Netto, 2004). For shallow marine sediments, such as estuaries and coastal lagoons, the understanding of the dynamics of more than one component of the benthos is particularly important, as these environments are usually subjected to major short-term oscillations in their physical and chemical conditions.

Of three components of the benthos, the macrofauna is largely the best described from the Brazilian estuaries (see Bemvenuti et al., 1992; Lana et al., 1996; Bemvenuti, 1998). On the other hand, there are only a few studies involving estuarine microphytobenthos (Sousa, 1983; Sousa \& David, 1995) or meiofauna (Dalto \& Albuquerque, 2000; Gomes et al., 2002; Somerfield et al., 2003; Rosa \& Bemvenuti, 2005). For the meiofauna, all these studies have identified the organisms only to higher taxonomic level (phyla or class). There is no information on the joint distribution and temporal variability of these benthic components under the same environmental constraints.

The Brazilian south and southeast coasts are characterized by the presence of a number of coastal lagoons and estuaries (Seeliger \& Kjerfve, 2001). Within this region, the Laguna Estuarine System is one of the largest formations (Giannini, 2002). Laguna is an important and traditional fishing port where some 8,000 artisanal fishermen make their living. Recently, shrimp farming has also played an important role of environmental relevance and in the economy. In fact, since 1998 the shrimp farming production has increased by some $4,000 \%$, attaining an annual production of 4,267 tons (ICEPA, 2005). In addition, as with many of the Brazilian coastal systems, Laguna suffers from unplanned coastal development and poor land occupation. There are very few studies of any aspect of the marine sciences relating to the Laguna Estuarine System. For the benthos there is no single data available.

This study deals with the structure of benthic communities in the Laguna Estuarine System, South Brazil. It analyses comparatively the spatial distribution and the temporal variability of the microphytobenthos, meiofauna and macrofauna along the shallow sublittoral bottoms of the estuarine system. Sediment chlorophyll $a$ and phaeopigment biomass, meiofauna - particularly nematodes, macrofauna composition and abundance were determined, and the first account of benthic communities in the area is given to serve as a baseline for future monitoring programs.

Study Area

The Laguna Estuarine System, located in the State of Santa Catarina, on the southern coast of Brazil (S 2812' E 48³8'; Fig. 1), is a choked lagoon (sensu Kjerfve, 1988) with an area of $184 \mathrm{~km}^{2}$. The system is composed of three main lagoons lying parallel to the shore line and connected one to another and with the adjacent ocean by narrow channels (Fig.1). They are: Mirim, in the north; Imaruí, the largest lagoon in the middle of the system; Santo Antonio, in the south making the connection with the ocean. Each lagoon receives the freshwater input of two rivers, the largest contribution coming from the river Tubarão, which follow into the Santo Antonio Lagoon and has an annual mean discharge of $50 \mathrm{~m}^{3} / \mathrm{s}$ (SDM, 1997). The Laguna Estuarine System is separated from the ocean by a sand barrier with large dune fields in the north. Further south, most of the sand dunes have been destroyed for human occupation. The western portion of the estuarine system is bounded by a high land formation, the Serra do Tabuleiro. Although the Laguna Estuarine System is affected by tides that cooscillate with those of the South Brazil coastal ocean (mean of $0.47 \mathrm{~m}$; Defant, 1961), the narrow entrance channel serves as a dynamic filter which largely eliminates tidal currents and water-level fluctuations inside the lagoon. The mean depth of the lagoons is around $2 \mathrm{~m}$, and the wind can, therefore, play a significant role in water circulation. The NE and S-SE winds are the most frequent in the summer and winter, respectively (EPAGRI, 2005). Mean air temperatures are around $13^{\circ} \mathrm{C}$ in the winter and $22^{\circ} \mathrm{C}$ in the summer; total mean annual rainfall is $1,260 \mathrm{~mm}$ with no marked differences over the year (EPAGRI, 2005).

\section{Materials and Methods}

\section{Sampling and Sample Processing}

Fifteen stations were sampled along the Laguna Estuarine System (Fig. 1) in December 2001 (summer) and July 2002 (winter). Samples were collected by diving at depths between 1 and $1.8 \mathrm{~m}$. At each station, 4 samples were taken for each component of the benthic community - microphytobenthos $(1 \mathrm{~cm}$ diameter core pushed to a depth of $1.2 \mathrm{~cm}$ ), meiofauna $(2 \mathrm{~cm} \times 10 \mathrm{~cm})$ and macrofauna $(15 \mathrm{~cm} \times 10 \mathrm{~cm})$. One sediment sample for the determination of organic matter and grain size was also taken at each station (10 $\mathrm{cm} \times 5 \mathrm{~cm}$ ). Depth, water salinity and temperature values were also recorded with an YSI 600 multiparameter system. 

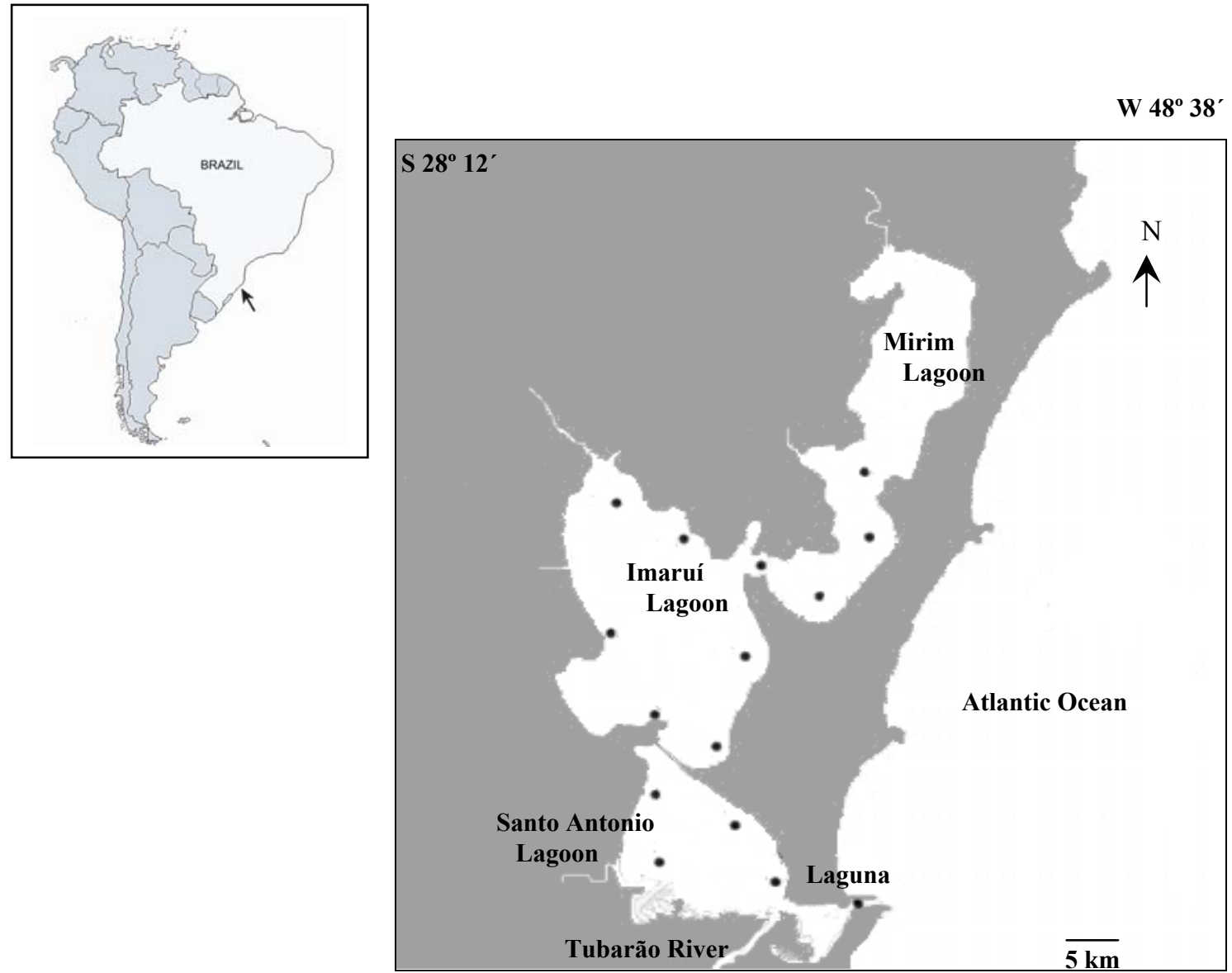

Fig. 1. Location of the Laguna Estuarine System, South Brazil, showing the position of the sample sites.

The sediment chlorophyll $a$ and phaeopigment biomass were processed in accordance with Plante \& Cuny (1978). Pigments were extracted by acetone $90 \%$ and the absorbance measured twice on two different wavelengths $(650$ and $750 \mathrm{~nm}$; spectrophotometer Hach dr-2000). To determine the degradation of chlorophyll to phaeopigments, $0.1 \mathrm{~N}$ $\mathrm{HCl}$ was added to the sample and the absorbance measured again. In order to determine whether the pigments are predominantly those of active cells or of degraded algal material from the bottom sediments or water column, the chlorophyll $a$ and phaeopigment ratio was determined (Riaux-Gobin \& Bourgoin, 2002).

Samples for meiofauna were sieved through a $63 \mu \mathrm{m}$ mesh and extracted by flotation in Ludox TM
50 (specific gravity of 1.15). Samples were then evaporated to anhydrous glycerol and permanent slides made (Somerfield \& Warwick, 1996). Fixed macrofaunal samples (10\% formalin) were sieved through a $0.5 \mathrm{~mm}$ mesh and preserved in $70 \%$ alcohol. All invertebrates were identified into the lowest possible taxonomic level and counted. The total sediment organic content was determined with $\mathrm{H}_{2} \mathrm{O}_{2}-$ $40 \%$ and the grain size was measured by sieve and pipette methods (Kettler et al., 2001).

\section{Data Analyses}

Data were analyzed using univariate and multivariate statistical techniques. The univariate descriptors used for the fauna were number of species, 
density, Shannon-Wiener diversity index $\left(\log _{2}\right)$ and evenness (Pielou's J). Test for differences in the fauna univariate measures and microphytobenthos (chlorophyll $a$ and phaeopigment biomass) between lagoons (Mirim, Imaruí and Santo Antonio) and periods (winter and summer) were carried out using a two-way ANOVA (Sokal \& Rohlf, 1997). In order to test the assumption of homogeneity of variances, Cochran's $\mathrm{C}$ tests were applied and where necessary, data were $\log (\mathrm{x}+1)$ transformed. The post-hoc HSDTukey tests were applied when differences were significant $(\mathrm{p}<0.05$; Sokal \& Rohlf, 1997). Ranked lower triangular similarity matrices derived from macrofauna, meiofauna and nematode abundance were then constructed using the Bray-Curtis similarity measure on $\log (x+1)$ transformed data. Formal significance tests for differences in the multivariate structure of benthic communities between lagoons were performed using the ANOSIM permutation test (Clarke \& Green, 1988)

Differences in the environmental variables total organic content, percentage of sand and silt, mean grain size, sorting, sediment heterogeneity (Lana, 1986), salinity and temperature values - were also tested between lagoons and periods by a two-way
ANOVA. Pearson product-moment correlations were performed for all the abiotic and biotic univariate data. The relationships between multivariate community structure and combinations of abiotic data were analyzed using the Bio-Env procedure (Clarke \& Ainsworth, 1993) to define the variables that best explain the faunistic structure.

\section{RESULTS}

\section{Environmental Data}

Salinity values varied between 3 and 20 and were significantly higher in the Santo Antonio (mean 19) and lower in the Mirim Lagoon (up to 6). In all the lagoons, salinity values were significantly higher in the winter than in the summer (Table 1). Total organic sediment content was significantly higher in the inner lagoon, Mirim, and did not vary significantly between sampling periods (Table 1). The results of the 2-way ANOVA tests showed that variations in all other abiotic data among the lagoons were dependent on sampling period and lagoon (Table 1). Mirim lagoon showed the highest variation in the sediment properties between the two seasons.

Table 1. Mean and standard deviation for environmental variables of each lagoon of the Laguna Estuarine System in the two sampling periods, and significance levels of the two-way ANOVA testing effect of location (lagoons) and periods. Differences between factors determined by HSD-Tukey post hoc comparisons. Bold $p$ values: significant differences. M: Mirim Lagoon; I: Imaruí Lagoon; SA: Santo Antonio Lagoon; W: Winter; S: Summer.

\begin{tabular}{|c|c|c|c|c|c|c|c|c|}
\hline & \multicolumn{3}{|c|}{ Lagoons (L) } & \multicolumn{2}{|c|}{ Periods (P) } & \multicolumn{3}{|c|}{ Two-way ANOVA } \\
\hline & $\begin{array}{l}\text { Mirim } \\
\text { (M) }\end{array}$ & $\begin{array}{c}\text { Imaruí } \\
\text { (I) }\end{array}$ & $\begin{array}{c}\text { Santo } \\
\text { Antonio } \\
\text { (SA) }\end{array}$ & $\begin{array}{l}\text { Winter } \\
\text { (W) }\end{array}$ & $\begin{array}{l}\text { Summer } \\
\text { (S) }\end{array}$ & $\mathbf{L}$ & $\mathbf{P}$ & $\mathbf{L} \times \mathbf{P}$ \\
\hline Salinity & $\begin{array}{c}5 \\
(1)\end{array}$ & $\begin{array}{l}14 \\
(3)\end{array}$ & $\begin{array}{l}20 \\
(4)\end{array}$ & $\begin{array}{l}18 \\
(6)\end{array}$ & $\begin{array}{l}11 \\
(6)\end{array}$ & $\begin{array}{c}\mathbf{0 . 0 0 1} \\
(\mathrm{SA}>\mathrm{I}>\mathrm{M})\end{array}$ & $\begin{array}{l}\mathbf{0 . 0 0 0 1} \\
(\mathrm{W}>\mathrm{S})\end{array}$ & 0.64 \\
\hline $\begin{array}{l}\text { Total organic } \\
\text { content }(\%)\end{array}$ & $\begin{array}{l}6.9 \\
(3.3)\end{array}$ & $\begin{array}{c}2.3 \\
(0.7)\end{array}$ & $\begin{array}{c}3.1 \\
(3.0)\end{array}$ & $\begin{array}{c}3.2 \\
(3.1)\end{array}$ & $\begin{array}{l}5.5 \\
(3.3)\end{array}$ & $\begin{array}{c}\mathbf{0 . 0 3} \\
(\mathrm{M}>\mathrm{I}, \mathrm{SA})\end{array}$ & 0.7 & 0.1 \\
\hline Sand $(\%)$ & $\begin{array}{l}91.9 \\
(15.9)\end{array}$ & $\begin{array}{c}85.1 \\
(24.7)\end{array}$ & $\begin{array}{l}96.8 \\
(7.4)\end{array}$ & $\begin{array}{l}93.1 \\
(14.3)\end{array}$ & $\begin{array}{l}94.5 \\
(15.2)\end{array}$ & 0.09 & 0.38 & 0.01 \\
\hline Silt (\%) & $\begin{array}{c}8 \\
(15.9)\end{array}$ & $\begin{array}{c}14.4 \\
(24.7)\end{array}$ & $\begin{array}{l}3.15 \\
(7.4)\end{array}$ & $\begin{array}{l}8.6 \\
(13.9)\end{array}$ & $\begin{array}{c}5.5 \\
(15.2)\end{array}$ & 0.09 & 0.38 & 0.01 \\
\hline $\begin{array}{l}\text { Grain size } \\
\quad(\mathbf{m m})\end{array}$ & $\begin{array}{c}0.18 \\
(0.06)\end{array}$ & $\begin{array}{c}0.16 \\
(0.07)\end{array}$ & $\begin{array}{c}0.15 \\
(0.03)\end{array}$ & $\begin{array}{c}0.14 \\
(0.04)\end{array}$ & $\begin{array}{c}0.17 \\
(0.05)\end{array}$ & 0.11 & 0.85 & 0.04 \\
\hline Sorting & $\begin{array}{c}0.62 \\
(0.49)\end{array}$ & $\begin{array}{l}0.84 \\
(0.6)\end{array}$ & $\begin{array}{c}0.45 \\
(0.28)\end{array}$ & $\begin{array}{c}0.67 \\
(0.46)\end{array}$ & $\begin{array}{c}0.51 \\
(0.41)\end{array}$ & $\begin{array}{c}\mathbf{0 . 0 3} \\
(\mathrm{M}, \mathrm{I}>\mathrm{SA})\end{array}$ & 0.21 & 0.02 \\
\hline $\begin{array}{c}\text { Sediment } \\
\text { heterogeneity }\end{array}$ & $\begin{array}{c}1.7 \\
(0.6)\end{array}$ & $\begin{array}{l}1.5 \\
(0.4)\end{array}$ & $\begin{array}{c}1.1 \\
(0.4)\end{array}$ & $\begin{array}{l}1.4 \\
(0.5)\end{array}$ & $\begin{array}{c}1.2 \\
(0.5)\end{array}$ & $\begin{array}{c}\mathbf{0 . 0 1} \\
(\mathrm{M}>\mathrm{I}, \mathrm{SA})\end{array}$ & 0.13 & 0.03 \\
\hline $\begin{array}{l}\text { Chlorophyll } a \\
\left(\mathbf{m g} \cdot \mathrm{m}^{-2}\right)\end{array}$ & $\begin{array}{c}107 \\
(247.8)\end{array}$ & $\begin{array}{l}350.5 \\
(677)\end{array}$ & $\begin{array}{l}263.6 \\
(679.4)\end{array}$ & $\begin{array}{c}15.0 \\
(35.5)\end{array}$ & $\begin{array}{c}498.2 \\
(775.9)\end{array}$ & 0.07 & $\begin{array}{l}\mathbf{0 . 0 0 0 1} \\
(\mathrm{S}>\mathrm{W})\end{array}$ & 0.9 \\
\hline $\begin{array}{l}\text { Phaeopigments } \\
\left(\mathbf{m g} \cdot \mathrm{m}^{-2}\right)\end{array}$ & $\begin{array}{c}190.3 \\
(226.7)\end{array}$ & $\begin{array}{c}509.2 \\
(762.2)\end{array}$ & $\begin{array}{c}489.8 \\
(1200.6)\end{array}$ & $\begin{array}{l}158.1 \\
(152.5)\end{array}$ & $\begin{array}{c}677.3 \\
(1149.2)\end{array}$ & 0.85 & $\begin{array}{l}\mathbf{0 . 0 0 0 1} \\
(\mathrm{S}>\mathrm{W})\end{array}$ & 0.45 \\
\hline $\begin{array}{c}\text { ratio } \\
\text { Chl } a: \text { Phaeo }\end{array}$ & $\begin{array}{c}0.5 \\
(0.6)\end{array}$ & $\begin{array}{c}22.3 \\
(152.4)\end{array}$ & $\begin{array}{l}0.67 \\
(0.85)\end{array}$ & $\begin{array}{c}0.3 \\
(0.4)\end{array}$ & $\begin{array}{c}18.3 \\
(136.2)\end{array}$ & 0.95 & $\begin{array}{c}\mathbf{0 . 0 1} \\
(\mathrm{S}>\mathrm{W})\end{array}$ & 0.26 \\
\hline
\end{tabular}


Significant interactions between the factors lagoon and period from the ANOVA tests for the sediment properties are shown in Figure 2. Sediments along the Laguna Estuarine System were more homogeneous during the summer, and mean grain size, sand percentages, sorting and sediment heterogeneity did not differ significantly among the lagoons. In the winter, on the contrary, sediment characteristics varied only in the Mirim Lagoon: sediment mean grain size and sand percentages decreased, whilst sorting and heterogeneity significantly increased (Fig. 2).
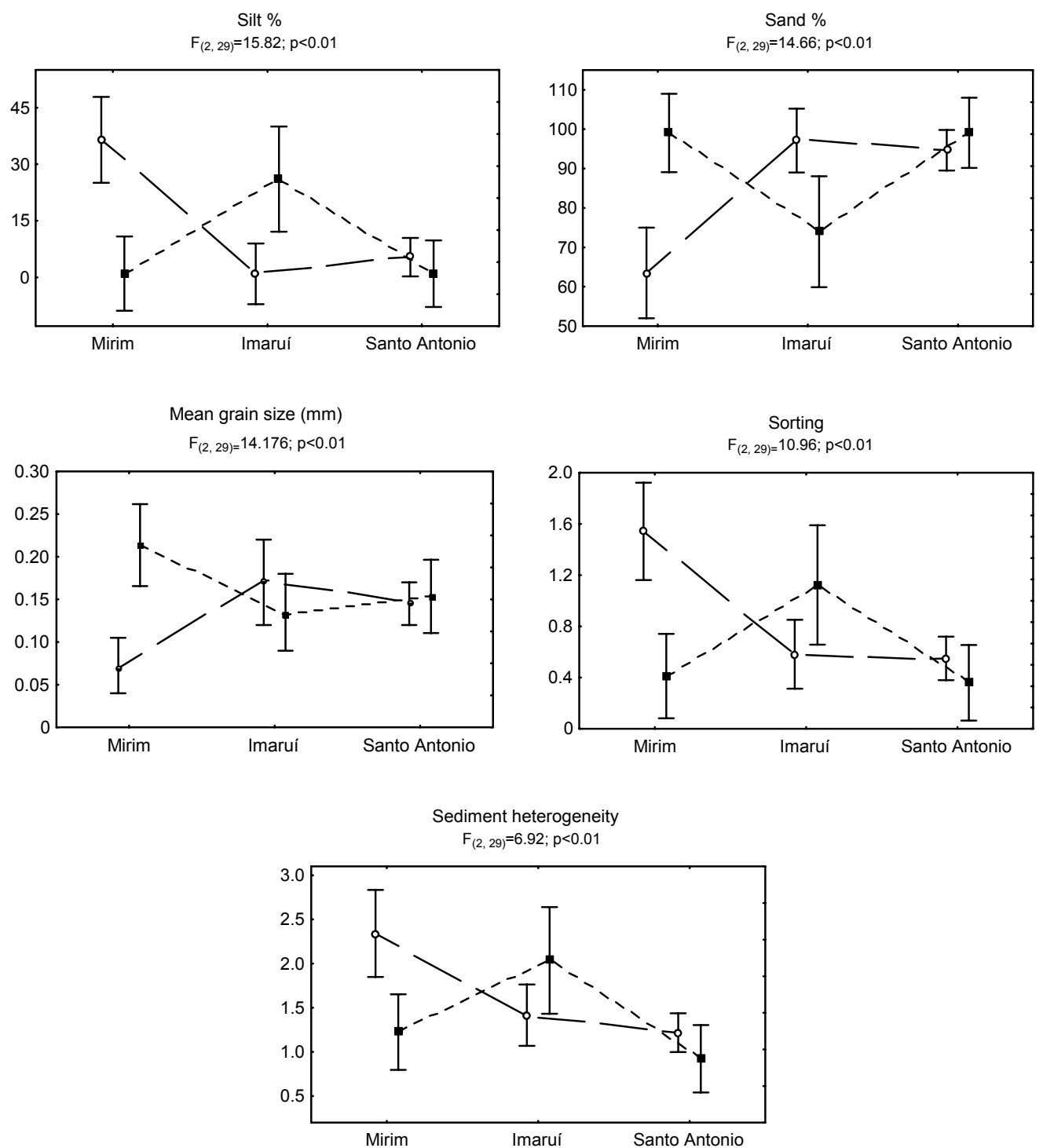

Fig. 2. F-ratios, significance level from 2-way ANOVA and means and 95\% confidence intervals for the sediment properties in the lagoons of the Laguna Estuarine System in the two sampling periods (ロ-summer and $\circ$-winter). 
Microphytobenthos

Sediment chlorophyll $a$ and phaeopigment biomass, as well as the chl a:phaeopigment ratio, did not vary significantly between lagoons and their values were significantly higher in summer (Table 1). The sediment chlorophyll $a$ biomass ranged from 16 to $2,298 \mathrm{mg} \cdot \mathrm{m}^{-2}$ in the summer, and between 0 and 76 mg. $\mathrm{m}^{-2}$ in the winter (Fig. 3). Phaeopigments ranged from 195 to $2,021 \mathrm{mg} \cdot \mathrm{m}^{-2}$ in the summer and 31 to 322 $\mathrm{mg} . \mathrm{m}^{-2}$ in the winter (Fig. 3). Significantly higher values of the chlorophyll $a$ to phaeopigment ratio in the summer indicated that most of the pigments were active chlorophyll $a$ (Fig. 3, Table 1).

\section{Macrofauna}

A total of 36 macrofaunal species were registered in both sampling periods. The gastropod Heleobia australis, the tanaidean Kalliapseudes schubartti and an unidentified species of Ostracoda were the most abundant forms, representing $85.5 \%$ of the total fauna. $H$. australis was the most abundant species in all the lagoons, except during summer in the
Mirim lagoon, where $K$. schubartii dominated numerically (Fig. 4). Highest densities of $H$. australis were recorded in the summer in the Santo Antonio lagoon with values up to 63,300 inds. $m^{-2} . K$. schubartii, on the contrary, showed higher densities in the inner lagoon (maximum value of 3,900 inds. ${ }^{-2}$ in the summer), decreasing towards Santo Antonio (Fig. 4). The highest densities of ostracods were registered in Santo Antonio, and lowest in Imaruí, both being winter values (Fig. 4).

The number of macrobenthic species was significantly higher in the Mirim Lagoon (mean of 10 species) and did not differ between Imaruí and Santo Antonio (mean of 8 species; Table 2; Fig. 5). The number of species did not differ between sampling periods (Table 2; Fig. 5). Macrofauna densities oscillated between 300 and 166,850 inds. $\mathrm{m}^{-2}$ and did not differ significantly among lagoons (Table 2) but were significantly higher in summer than in winter (Table 2). Both diversity and evenness values were significantly higher in the Mirim Lagoon and did not differ significantly between periods (Table 2; Fig. $5)$.
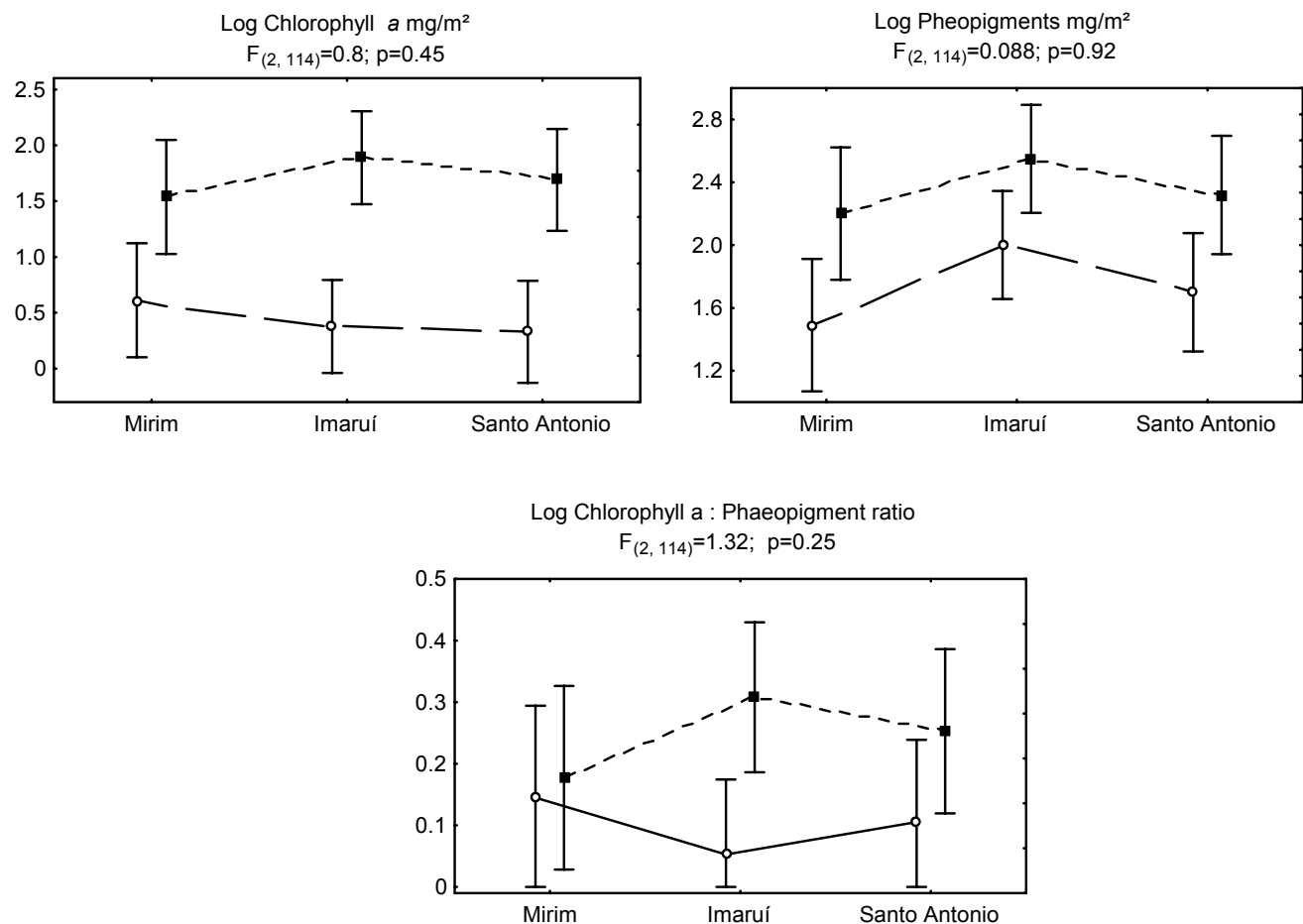

Fig. 3. F-ratios, significance level from 2-way ANOVA and means and 95\% confidence intervals for the biomass of chlorophyll, phaeopigments and chlorophyll:phaeopigment ratio of the sediment in the lagoons of the Laguna Estuarine System

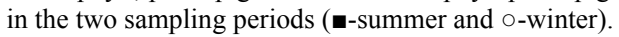



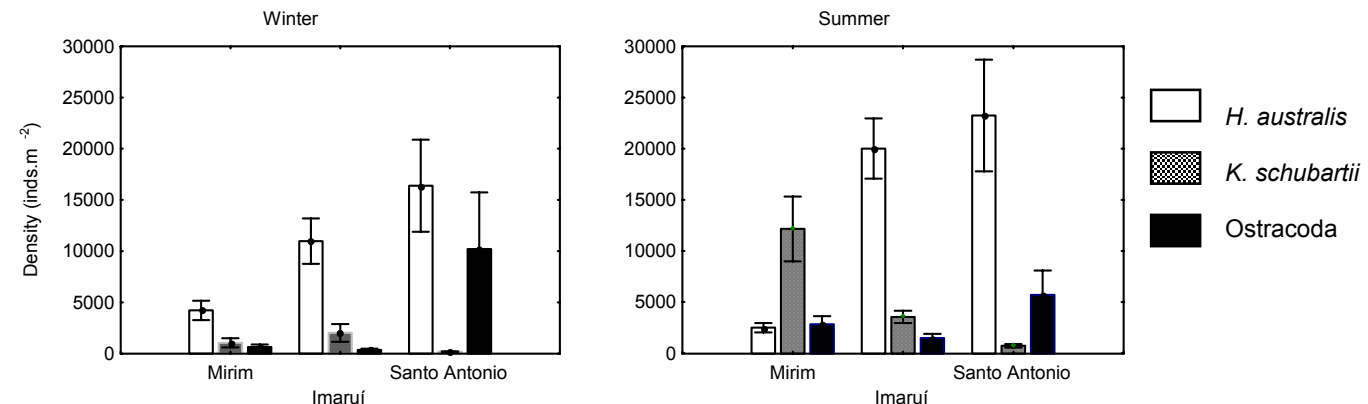

Fig. 4. Means and standard error for the three most abundant macrofauna species in the lagoons of the Laguna Estuarine System in the two sampling periods.

Table 2. Significance levels from the two-way ANOVA testing effect of location (L) and period (P). Differences between factors determined by HSD-Tukey post hoc comparisons. Bold $p$ values: significant differences. M: Mirim Lagoon; I: Imaruí Lagoon; SA: Santo Antonio Lagoon; W: Winter; S: Summer.

\begin{tabular}{|c|c|c|c|}
\hline & L & $\mathbf{P}$ & $L \times P$ \\
\hline \multicolumn{4}{|l|}{ Macrofauna } \\
\hline Number of species & $\begin{array}{c}0.009 \\
\text { M>I, SA }\end{array}$ & 0.083 & 0.84 \\
\hline Density & 0.72 & $\begin{array}{c}\mathbf{0 . 0 0 0 1} \\
\mathrm{S}>\mathrm{W}\end{array}$ & 0.7 \\
\hline Diversity & $\begin{array}{c}\mathbf{0 . 0 0 0 1} \\
\mathrm{M}>\mathrm{I}, \mathrm{SA}\end{array}$ & 0.8 & 0.96 \\
\hline Evenness & $\begin{array}{c}\mathbf{0 . 0 0 0 1} \\
\mathrm{M}>\mathrm{I}, \mathrm{SA}\end{array}$ & 0.71 & 0.93 \\
\hline \multicolumn{4}{|l|}{ Meiofauna } \\
\hline Number of taxa & 0.61 & 0.88 & 0.49 \\
\hline Density & 0.18 & $\begin{array}{c}\mathbf{0 . 0 0 0 4} \\
W>S\end{array}$ & 0.19 \\
\hline Diversity & $\begin{array}{c}\mathbf{0 . 0 0 0 1} \\
\mathrm{M}, \mathrm{I}<\mathrm{SA}\end{array}$ & 0.42 & 0.14 \\
\hline Evenness & $\begin{array}{c}\mathbf{0 . 0 0 0 1} \\
\mathrm{M}, \mathrm{I}<\mathrm{SA}\end{array}$ & 0.47 & 0.23 \\
\hline \multicolumn{4}{|l|}{ Nematodes } \\
\hline Number of species & $\begin{array}{c}\mathbf{0 . 0 0 0 1} \\
\mathrm{M}>\mathrm{I}, \mathrm{SA}\end{array}$ & $\begin{array}{c}\mathbf{0 . 0 0 0 4} \\
W>S\end{array}$ & 0.45 \\
\hline Density & $\begin{array}{c}\mathbf{0 . 0 0 0 1} \\
\mathrm{M}, \mathrm{I}>\mathrm{SA}\end{array}$ & 0.17 & 0.83 \\
\hline Diversity & $\begin{array}{c}\mathbf{0 . 0 0 0 1} \\
\mathrm{M}>\mathrm{I}, \mathrm{SA}\end{array}$ & 0.06 & 0.75 \\
\hline Evenness & $\begin{array}{c}\mathbf{0 . 0 0 1 5} \\
\mathrm{M}>\mathrm{I}, \mathrm{SA}\end{array}$ & 0.48 & 0.58 \\
\hline
\end{tabular}

The results of the ANOSIM tests confirmed that macrofauna structure differed significantly among the lagoons (Table 3). The ANOSIM tests also showed that Imaruí and Santo Antonio are the most closely similar of the lagoons in both periods (lower R values, Table 3).
Meiofauna

The meiofauna was composed of 20 higher taxa, nematodes (74\%), tardigrades $(11 \%)$ and copepods $(9 \%)$ being the most abundant groups. The nematodes were the numerically dominant group in all 
the lagoons and periods, and their mean density tends to decrease from the innermost to the Santo Antonio lagoon (Fig. 6). The highest densities of nematodes were recorded in the Mirim lagoon in the summer $\left(5,590\right.$ inds. $\left.10 \mathrm{~cm}^{-2}\right)$. Thus, differently from the nematodes, both tardigrade and copepod densities increased towards the Santo Antonio lagoon, especially in the winter, when the maximum densities recorded were 4,261 and 8,012 inds. $10 \mathrm{~cm}^{-2}$, respectively (Fig. 6)

The number of meiofauna taxa did not differ significantly between the lagoons or sampling periods (Table 2). Meiofauna densities ranged from 47 to 8,023 inds. $10 \mathrm{~cm}^{-2}$ and did not differ significantly among the lagoons either. However, contrary to the macrofauna, meiofauna density values were significantly higher in the winter (Table 2; Fig. 5). Both diversity and evenness values were significantly higher in Santo Antonio and did not differ between periods (Table 2; Fig. 5).

The results of ANOSM tests (Table 3) showed that differences in meiofauna assemblages between the lagoons were independent of the sampling period. The meiofauna community structure in Santo Antonio differed significantly from those of the other lagoons in both periods (Table 3). Within each lagoon, meiofauna temporal variability was significant in both Santo Antonio and Mirim (Table 3).

\section{Nematodes}

A total of 74 putative nematode species (68 genera) belonging to 26 families were recorded in the Laguna Estuarine System. Desmodora (Desmodora) sp.1, Terschllingia sp. and Microlaimus sp. were numerically the most important groups, corresponding to $52 \%$ of the total nematodes collected. Of the 74 species, only 13 had a frequency of 50 or more. Theristus sp. 1 and Terschllingia sp. were the most constant species, occurring at $95 \%$ and $91 \%$ of the stations, respectively. Mean densities of Desmodora (Desmodora) sp.1 decreased from Mirim (with maximum density of 2,630 inds. $10 \mathrm{~cm}^{-2}$ ) towards the Santo Antonio lagoon in both sampling periods (Fig. 7). Terschllingia sp. was the most abundant species in Imaruí in both summer and winter (Fig. 7) Density values of Sabatieria sp. 1 were low in the Mirim lagoon, but increased at Imaruí and Santo Antonio (Fig. 7).

Table 3. R values and significance levels (p) from 2-way ANOSIM tests for differences in the multivariate community structure of benthic fauna from the Laguna Estuarine System in the two sampling periods. M: Mirim Lagoon; I: Imaruí Lagoon; SA: Santo Antonio Lagoon

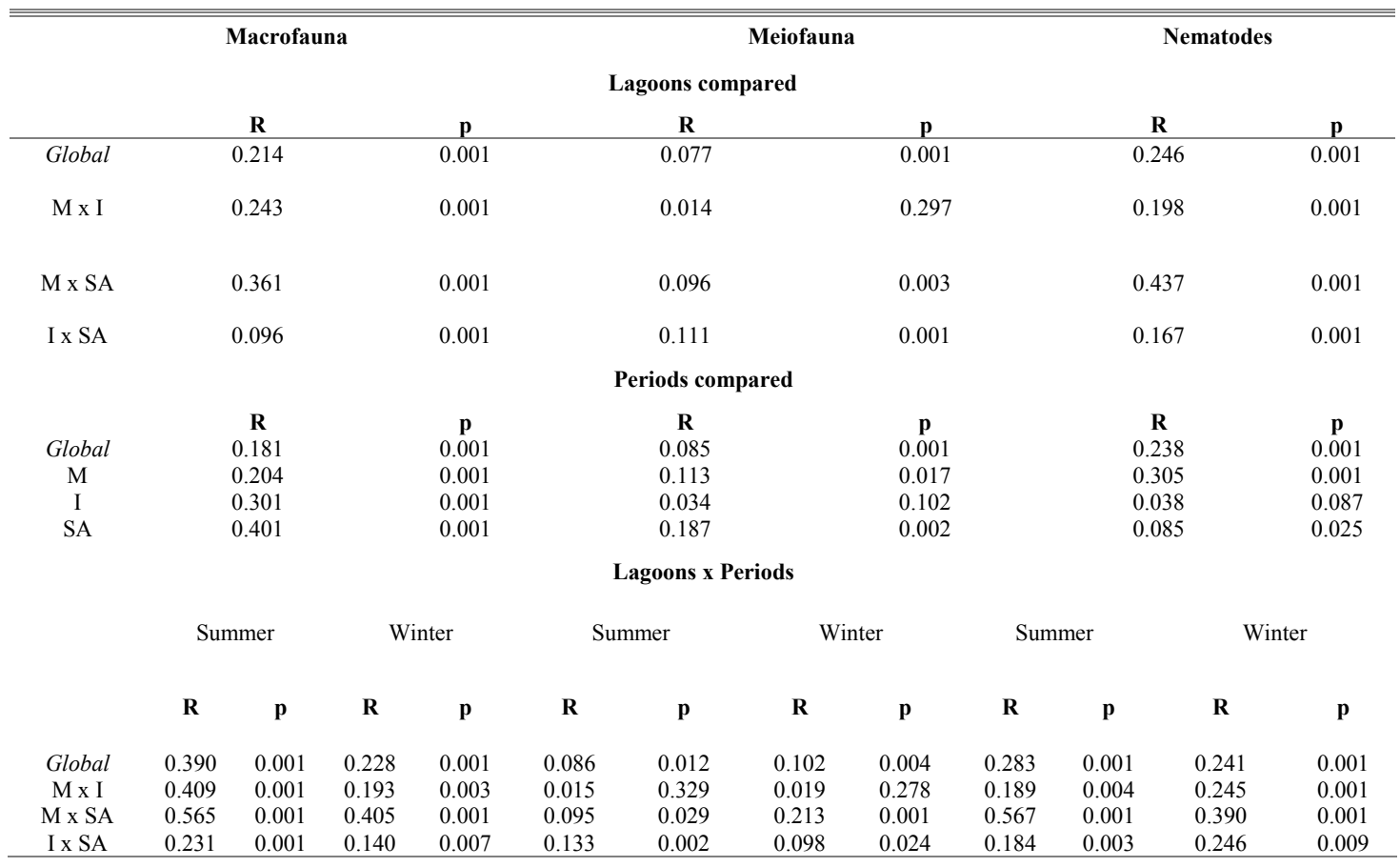



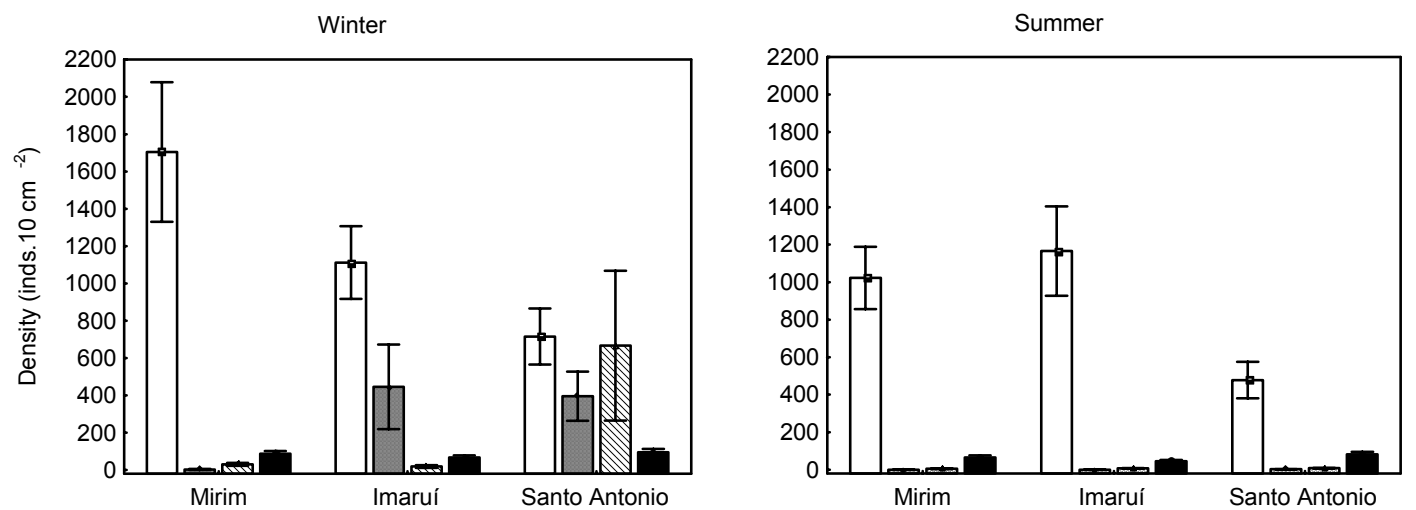

Fig. 6. Means and standard error for the three most abundant meiofaunal taxonomic groups in the lagoons of the Laguna Estuarine System in the two sampling periods.

Legend: white $=$ nematoda; dark dashed $=$ copepoda; light dashed $=$ tardigrada $;$ black $=$ others .
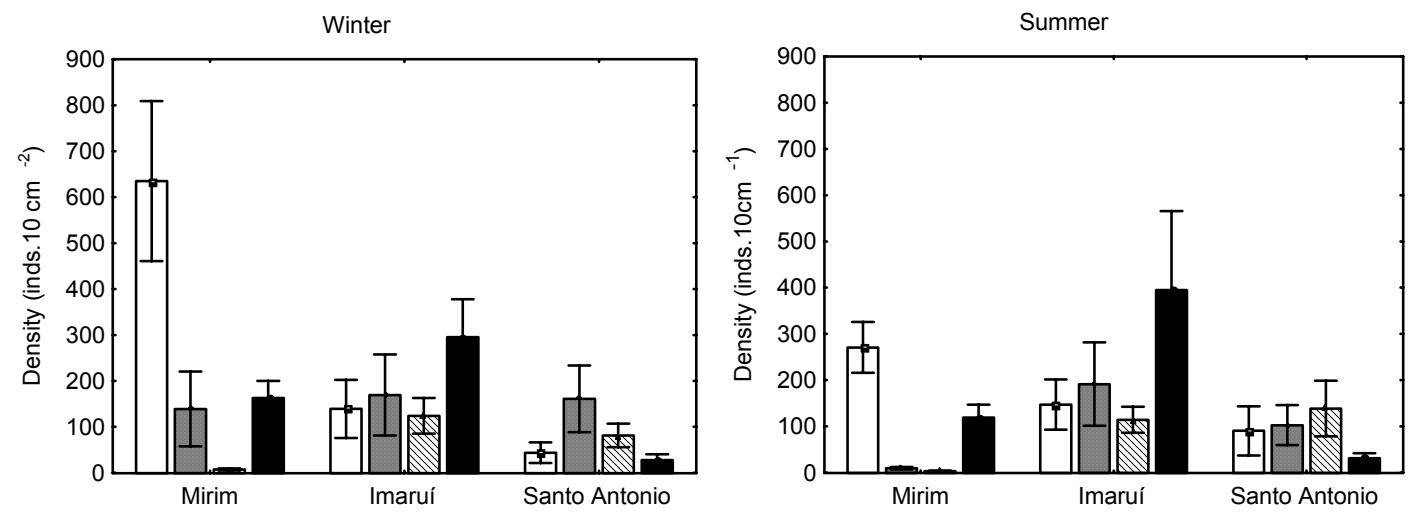

Fig. 7. Means and standard error for the four most abundant nematode species in the lagoons of the Laguna Estuarine System in the two sampling periods.

Legend: white $=$ Desmodora sp.1; dark dashed = Microlaimus sp.; light dashed $=$ Sabatieria sp.; black $=$ Terschillingia sp.

The spatial and temporal distribution of the relative abundance of nematode feeding types, according to Wieser (1953), is shown on Figure 8. The nonselective deposit feeder (1B) and the epigrowth feeder $(2 \mathrm{~A})$ nematodes were the numerically dominant forms. In the Mirim lagoon, both $1 \mathrm{~B}$ and $2 \mathrm{~A}$ represented more than $70 \%$ of the nematodes, where $2 \mathrm{~A}$ were more abundant in the winter and $1 \mathrm{~B}$ forms more abundant in the summer. The deposit feeder and epigrowth feeder nematodes showed, roughly, a similar value of relative abundance in Imaruí (nonselective deposit feeder slightly more abundant) in both periods. In the outer lagoon, Santo Antonio, nonselective deposit feeder nematodes were the most abundant form in winter and summer (Fig. 8).

The species number, diversity and evenness values were significantly higher in Mirim than in Imaruí and Santo Antonio (Table 2; Fig. 5). Nematode densities were also significantly higher in Mirim and lower in Santo Antonio, but density values did not differ between Mirim and Imaruí (Table 2). No significant interactions were detected for any of the nematode univariate descriptors (Table 2). Temporal variability was only detected in the number of nematode species, which was significantly higher in the winter $(16$ species) than in the summer (mean of 12; Table 2; Fig. 5).

The results of the ANOSIM tests showed that differences among the lagoons, as well as between periods, were all significant (Table 3). Nematodes temporal variability within each lagoon, similarly to the results for meiofauna, was not significant only for the Imaruí Lagoon (Table 3).

\section{Benthic Communities and Environmental Variables Interactions}

The results of the Pearson product-moment 

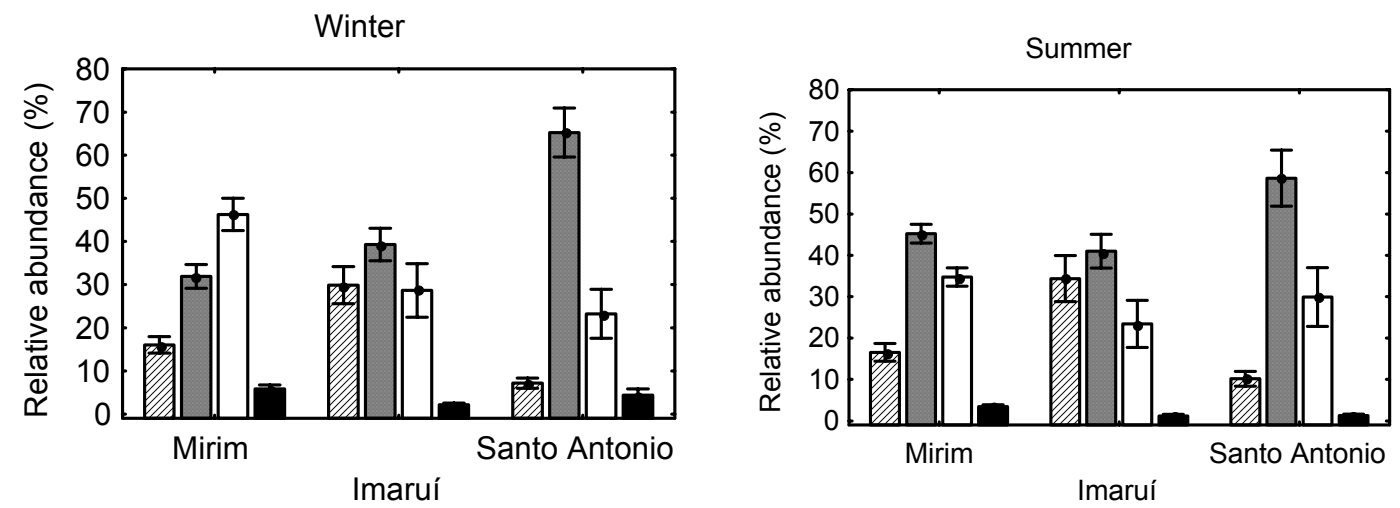

Fig. 8. Means and standard error for the four nematode feeding types (1A-selective deposit feeders; 1B-nonselective deposit feeders; 2A-epigrowth feeders, 2B-predators/omnivorous) in the lagoons of the Laguna Estuarine System in the two sampling periods.

Legend: white $=1 \mathrm{~A}$; dark dashed $=1 \mathrm{~B} ;$ light dashed $=2 \mathrm{~A} ;$ black $=2 \mathrm{~B}$.

correlations of the univariate data (fauna $\mathrm{x}$ abiotic) showed that the number of macrobenthic species and density were negatively correlated with fine percentages (-0.6), and positively correlated with mean grain size and sand percentages $(0.6 ; p<0.05)$. For the meiofauna, no significant correlation was detected between univariate descriptors and environmental variables. On the other hand, the number of nematodes species was negatively correlated with salinity $(-0.6)$.

The interrelationships between the multivariate structure of benthic community and combinations of abiotic variables were examined by the BIO-ENV procedure. Variations in both macrofauna and nematode assemblages were best explained by the sand percentages and salinity. However, while the multivariate structure of the macrofauna showed a correlation value of 0.47 , sand percentages and salinity values explained $65 \%$ of nematode variability.

\section{Discussion}

The results of this study showed that the environmental variables and the structure of benthic communities among the three main lagoons of the Laguna Estuarine System differed significantly, and that these differences were dependent on sampling period. This study confirmed that, although the benthic communities are under the same stressors (e.g., salinity oscillations, sediment composition), they showed significantly different patterns in spatial distribution and temporal variability.

There are no published studies on the hydrographic data of Laguna, but it is already known that water circulation in chocked lagoons is mainly wind-driven (Kjerfve, 1988; Miranda et al., 2002;
Castelão \& Möller Jr., 2003). Wind controls salinity distribution and water levels, but rainfall and river discharge may also generate periodical gradients with higher water levels after rainy periods (Garcia, 1996; Miranda et al., 2002). The Laguna region is under the influence of NE-SE winds, where those from the NE (mean velocity of $6 \mathrm{~m} . \mathrm{s}^{-1}$ ) occur during $44 \%$ of the year and those from the S-SE (mean velocity of 7.4 $\mathrm{m} . \mathrm{s}^{-1}$ ) during $32 \%$ (EPAGRI, 2005). The salinity values recorded in this study suggested that during summer, when the wind blows mainly from the NE, water masses are frequently pushed towards the southern margins of the lagoon and consequently the salinity values decreased. Contrary, in the winter period with the strong S-SE winds, the marine waters are more easily able to get into the Laguna Estuarine System, thus increasing salinity values.

Apart from oscillations due to river discharges, wind also appears to be an important and direct factor regulating the temporal variation of the sediments in the Laguna Estuarine System. Our results (significant increase of sand percentages in the Mirim Lagoon in the summer) and observations strongly suggested a link between wind direction and velocity, presence of sand dunes and sediment properties along the Laguna shallow bottoms, particularly in the northern portion of the Mirim Lagoon. The sand barrier in the northern portion is relatively narrower than in the central and southern portions, and is characterized by the presence of larger dunes fields. Most of the dune fields in the central and southern portion have been removed for urban occupation. It is therefore suggested that in the summer, with a predominance of NE winds, sand from the dunes might be carried into the Laguna Estuarine System, as observed in the increase of sand percentages in the Mirim Lagoon. Also, the oscillation in sediment 
heterogeneity (Lana, 1986) could be caused by the interactions between the sand dunes and Mirim Lagoon bottom sediments. Although this hypothesis needs further investigation, it is in agreement with the model proposed by Boorman (1977) in which the transport of sand grains would need winds with velocities of above $6 \mathrm{~m} . \mathrm{s}^{-1}$. Such a wind velocity and direction is frequent enough in the summer at Laguna to transport sufficient sand from the sand dunes to the coastal lagoons as to affect local sediment properties.

The chlorophyll $a$ biomass of the Laguna Estuarine System (up to 2,298 $\mathrm{mg} \cdot \mathrm{m}^{-2}$ ) was characterized by values relatively higher than those of other subtidal areas along the Brazilian coast as well in other estuaries (Colijn \& Jonge, 1984; Santos et al., 1995). Such values are probably supported by muddy sand sediments and the low seston concentration of the Laguna Estuarine System, together with nutrient availability (Riaux-Gobin \& Borgoin, 2002). The chlorophyll $a$ biomass was significantly different between the periods, increasing the mean value from $15 \mathrm{mg} . \mathrm{m}^{-2}$ in the winter to $498.2 \mathrm{mg} \cdot \mathrm{m}^{-2}$ in summer time. These oscillations are usual and in the same range as those of other coastal environments in temperate climates (Seuront \& Spilmont, 2002). The microphytobenthos biomass showed a considerable spatial fluctuation along the Laguna System and the values did not differ significantly among the lagoons. These findings were probably a result of the very patchy distribution due to variations in the texture and relief of the sediment surface (Joergensen \& Revsbech, 1983; Jumars \& Nowell, 1984) or the micro-scale nutrient variations, irradiance and sediment water content (Blanchard, 1990). Besides, deposited pelagic algae can lead to benthic primary production of about $30-45 \%$ of total primary production (Riaux-Gobin et al., 2004).

The macrobenthic associations of the shallow subtidal Laguna Estuarine System are similar to those of other estuaries in South Brazil (Bemvenuti \& Netto, 1998; Lana, 1986b; Rosa-Filho \& Bemvenuti, 1998), but also resemble those of estuaries in Argentina (Samborombon Bay; Ieno \& Bastida, 1998) and in Uruguay (Rio del Plata; Giberto et al., 2004). Macrofauna was characterized by low species richness and the numerical dominance of species such as the gastropod Heleobia australis, the tanaidean Kalliapseudes schubartti and the bivalve Erodona mactroides. Also abundant are the polychaetes Laeonereis acuta, Heteromastus similis and Nephtys fluviatilis. In the Patos Lagoon, Bemvenuti \& Netto (1998) identified 40 macrofaunal species, whereas 36 species were registered in the Laguna Estuarine System, the majority of them were common for both sites. H. australis, K. schubartti and E. mactroides dominated the macrofaunal organisms in both shallow sublittoral lagoons.

The meiofauna composition along the Laguna Estuarine System is typical of estuaries; nematodes dominate with $60-90 \%$, followed by the copepods and tardigrades (Heip et al., 1985; Coull, 1999; Ozório et al., 1999). The genera found in the Laguna Estuarine System were similar to those in estuaries in other parts of the world (Ansari et al., 1980; Boucher, 1996; Heip et al., 1985; Soetaert et al., 1995; Tjeten, 1991). The Laguna System was characterized by the numerical dominance of nonselective deposit feeders and epigrowth feeders. The meiofauna of the Mirim lagoon was distinguished from those of the other lagoons by the presence and abundance of the Desmodoridae and Chromadoridae families and the few tylenchid specimens. The other two lagoons were characterized by Comesomatidae, Monhysteridae and Microlaimidae. The dominance of these nematodes is typical of estuaries, due to their high tolerance to salinity oscillations and the abundant food resources, such as microphytobenthos and organic detritus (Moens \& Vincx, 1997). However the preference and higher abundance of grazers belonging to the Desmodoridae and Chromadoridae in the innermost lagoon could be associated with the great availability of microphytobenthos in combination with sandy sediments. Most of the species belonging to these families are known to prefer sandy sediments, particularly with high microalgae availability (Heip et al., 1985).

The results of this study show that, in the Laguna Estuarine System, the differences among the lagoons depend on the components of the benthos. Whilst macrobenthic forms and nematodes were significantly more diverse at the inner stations (in the Mirim Lagoon), the number of meiofauna taxa did not differ significantly among the lagoons and the diversity and evenness were higher in Santo Antonio. These results contradict previous findings which present species diversity and richness as increasing with salinity values (Mclusky, 1971; Nybakken, 2001). Indeed, a large number of studies of estuarine areas have shown that species number is habitually positively correlated with salinity values, whether for macrofauna (e.g., Capitoli et al., 1978; Netto \& Lana, 1996; Barnes, 1984) or nematodes (Heip et al., 1985; Montagna \& Yoon, 1991).

However, a recent publication by Attrill (2002), has questioned the general model attributing changes in species diversity to changes in salinity gradients. Rather than the absolute salinity value, one of the major environmental factors influencing the distribution of organisms in estuaries is the salinity variation. The relationship between salinity and fauna diversity may also depend on the location of the sampling sites along the estuary (if intertidal, subtidal or shallow subtidal), the local tidal regime and 
circulation. Moreover, the nature of estuarine bottoms is also a key factor with regard to benthic fauna distribution on a large scale. The results of this study show that salinity range was greater in Santo Antonio (14 to 25) and lower in the Mirim Lagoon (3 to 6). Besides, sediment heterogeneity (Lana, 1986) was significantly higher in the Mirim Lagoon. The results show that both macrofauna and nematodes were significantly more diverse in the Mirim Lagoon, and this could be a response to lower salinity variation coupled with greater sediment heterogeneity. These results are in agreement with those presented by Warwick (1971) and Attrill (2002).

Temporal oscillations between the different benthic components in the Laguna Estuarine System also differ. Macrofauna was significantly more abundant in summer and meiofauna in winter. For the meiofauna, the temporal variability in density was due to the increase in groups such as copepods and tardigrades, rather than to the nematodes which did not vary significantly between sampling periods. These results are related to the different life strategies of the macrofauna and meiofauna, as well as to cyclical changes in salinity. Macrobenthic species generally present a life span longer than one year and the adult must thefore tolerate the full periodical range of environmental conditions. Thus spawning is also periodic and more or less synchronized (Warwick, 1984). Meiofauna, in contrast, have typically continuous reproduction and many features of there reproductive biology, such as high fertility, high generation turnover, no pelagic larval stage, that lead to higher population stability over time (Lee, 2002). This is particularly true for nematodes. In this study, this group maintained high abundances throughout the system in both seasons. The present data also suggest that meiofauna organisms are affected in different ways by salinity. Whilst nematodes were more diverse and abundant at the innermost lagoon in both seasons, other meiobenthic taxa were more abundant closer to the inlet channel in winter time. This is probably due to differences in salinity tolerances and osmotic regulation capacity among the meiobenthic taxa (Mclusky, 1971; Foster et al., 1998). Whilst tardigrades and especially copepods prefer higher salinities, marine nematodes tolerate very low salinity values (Joint et al., 1982; Pfannkuche \& Thiel, 1988) and show very efficient osmotic regulation (Foster et al., 1998).

\section{AcKnowledgements}

We would like to thank the Brazilian Navy (Laguna Office) for providing the boat for all our sampling campaigns. We would also thanks Fabiane Gallucci is for her help during sampling, Geraldo
Bacana for processing the sediment samples, and Eduardo Sierra and Alessandra Fonseca for providing the facilities for the microphytobenthos analysis. Further, two anonymous referees made constructive comments on the manuscript.

\section{$\mathrm{R}_{\text {EFERENCES }}$}

Albertelli, G.; Covvazzi-Harriague, A.; Danovaro, R.; Fabiano, M.; Fraschetti, S. \& Pusceddu, A. 1999. Differential responses of bacteria, meiofauna and macrofauna in a shelf area (Ligurian Sea, NW Mediterranean): role of food availability. J. Sea Res., 42:11-26.

Ansari, Z. A.; Parulekar, H. \& Jagtap, T. G. 1980. Distribution of sub-littoral meiobenthos off Goa coast, India. Hydrobiologia, 74:209-214.

Atrill, M. J. 2002. A testable linear model for diversity trends in estuaries. J. Anim. Ecol., 71:262-269.

Barnes, R. S. K. 1984. Estuarine Biology. $2^{\text {nd }}$. ed. Maryland, Edward Arnold Ltd. 76p.

Bemvenuti, C. E. 1998. Invertebrados Bentônicos. In: Seeliger, U.; Odebrecht, C. \& Castello, J. P. eds. Os ecossistemas costeiros e marinho do extremo sul do Brasil. Ecoscientia, Rio Grande. 326p.

Bemvenuti, C. E. \& Netto, S. A. 1998. Distribution and seasonal patterns of the sublittoral benthic macrofauna of Patos Lagoon (South Brazil). Rev. Brasil. Biol., 58:211221.

Bemvenuti, C. E.; Cattaneo, S. A. \& Netto, S. A. 1992. Características estruturais da macrofauna bentônica em dois pontos da região estuarial da Lagoa dos Patos, RS, Brasil. Atlântica, 4:5-27.

Blanchard, G. F. 1990. Overlapping microscale dispersion patterns of meiofauna and microphytobenthos. Mar. Ecol. Prog. Ser., 68:101-111.

Boorman, L. A. 1977. Sand dunes. In: Barnes, R.S.K. ed. The coastline. New York, John Wiley, p. 161-197.

Boucher, G. 1996. Structure and biodiversity of nematode assemblages in the SW lagoon of New Caledonia. Coral Reefs, 16:177-186.

Capitoli, R. R.; Bemvenuti, C. E. \& Gianuca, N. M. 1978. Estudos de ecologia bentônica na região estuarial da Lagoa dos Patos I - As comunidades bentônicas. Atlântica, 3:5-22.

Castelão, R. M. \& Möller Jr, O. L. 2003. Sobre a circulação tridimensional forçada por ventos na Lagoa dos Patos. Atlântica, 25(2):91-106.

Clarke, K. R. \& Ainsworth, M. 1993. A method of linking multivariate community structure to environmental variables. Mar. Ecol. Prog. Ser., 92:205-219.

Clarke, K. R. \& Green, R. H. 1988. Statistical design and analysis for a "biological effects" study. Mar. Ecol. Prog. Ser., 46:226-231.

Coull, B. C. 1999. Role of meiofauna in estuarine soft-bottom habitats. Austr. J. Ecol., 24:327-343.

Colijn, F. \& Jonge, V. N. 1984. Primary production of microphytobenthos in the Ems-Dollard estuary. Mar. Ecol. Prog. Ser., 104:185-196.

Dalto, A. G. \& Albuquerque, E. F. 2000. Meiofauna distribution in a tropical estuary of the South-Western Atlantic (Brazil). Vie Milieu., 50:151-162. 
Danovaro, R.; Tselepides, A.; Otegui, A. \& Della-Croce, N.;2000. Dynamics of meiofaunal assemblages on the continental shelf and deep-sea sediments of the Cretan Sea (NE Mediterranean): relationships with seasonal changes in food supply. Progr. Ocean., 46:367-400.

Defant, A. 1961 Physical Oceanography, vol I. Oxford, Pergamon Press. 729p

EPAGRI. 2005. Empresa de Pesquisa Agronômica e Extensão Rural de Santa Catarina - Centro Integrado de Meteorologia e Recursos Hídricos de Santa Catarina. http://www.epagri.rct-sc.br/.

Foster, S. J. 1998. Osmotic stress tolerance and osmoregulation of intertidal and subtidal nematodes. $\mathrm{J}$. expl. mar. Biol. Ecol., 224:109-125.

Gallucci, F. \& Netto, S. A. 2004. Effects of the passage of cold fronts over a coastal site: an ecosystem approach. Mar. Ecol. Prog. Ser., 281:79-92.

Garcia, C. A. E. 1996. Hydrographic characteristics. In: Seeliger, U.; Odebrecht, C. \& Castello, J. P. eds. Subtropical convergent environments, the coast and sea in the South-western Atlantic. Berlin, Springer-Verlag. $308 \mathrm{p}$.

Giannini, P. C. F. 2002. Complexo Lagunar Centro-Sul Catarinense. In: Schobbenhaus, C.; Campos, D.A.; Queiroz, E. T.; Winge, M. \& Berbert-Born, M. L. C. eds.. Sítios geológicos e paleontológicos do Brasil. Brasília, DF. DNPM/CPRM - Comissão Brasileira de Sítios Geológicos e Paleobiológicos (SIGEP), 554 p.

Giberto, D. A.; Bremec, C. S.; Acha, E. M. \& Mianzan, H. 2004. Large scale spatial patterns of benthic assemblages in the SW Atlantic: the Rio de la Plata estuary adjacent shelf waters. Estuar. coast. Shelf Sci., 61:1-13.

Gomes, C. A. A.; Santos, P. J. P.; Alves, T. N. C.; RosaFilho, J. S. \& Souza-Santos, L. P. 2002. Variação temporal da meiofauna em área de manguezal em Itamaracá-Pernambuco. Atlântica, 24:89-96.

Heip, C.; Vincx, M. \& Vranken, G. 1985. The ecology of marine nematodes. Oceanogr. Mar. Biol. a. Rev., 23:399489.

ICEPA. 2005. Instituto de Planejamento e Economia Agrícola de Santa Catarina. http://www.icepa.com.br/.

Ieno, E. N. \& Bastida, R. O. 1998. Spatial and temporal patterns in coastal macrobenthos of Samborombon Bay, Argentina: a case study of very low diversity. Estuaries, 21:690-699.

Jørgensen, B. B. \& Revsbech, N. P. 1983. Colourless sulphur bacteria, Beggiatoa spp. and Thiovolum spp., in $\mathrm{O}_{2}$ and $\mathrm{H}_{2} \mathrm{~S}$ microgradients. Appl. Environ. Microbiol. 45:1261-1270.

Joint, I. R.; Gee, J. M. \& Warwick, R. M. 1982. Determination of fine scale vertical distribution of microbes and meiofauna in an intertidal sediment. Mar. Biol., 72:157-164.

Jumars, P. A. \& Nowell, A. R. M. 1984. Fluid and sediment dynamic effects on marine benthic community structure. Am. Zool., 24:45-55.

Kettler, T. A.; Doran, J. W. \& Gilbert, T. L. 2001. Simplified method for soil particle-size determination to accompany soil-quality analyses. Soils. Sci. Soc. Am. J., 65:849-852.

Koop, K. \& Griffiths, C. L. 1982. The relative significance of bacteria, meio- and macrofauna on an exposed sandy beach. Mar. Biol., 66:295-300.

Kjerfve, B. 1994. Coastal Lagoons. In: Kjerfve, B. ed. Coastal Lagoon processes. Elsevier-Oceanographic
Series, 60, p. 1-8.

Kjerfve, B. 1988. Hydrodynamics of estuaries. Boca Raton. CRC Press. vol.1, 163p. \& vol.2, 125p.

Lana, P. C. 1986. Um novo índice para avaliar a heterogeneidade de sedimentos não consolidados. Arq. Biol. Tecn., 25:357-359.

Lana, P. C.; Camargo, M. G.; Brogim, R. A. \& Isaac, V. J. 1996. O bentos da costa brasileira. Avaliação crítica e levantamento bibliográfico (1858-1996). Rio de Janeiro, FREMAR. 432p.

Lee, D. L. 2002. The biology of nematodes. New York, Taylor \& Francis. 635p.

McLusky, D. S. 1971. Ecology of Estuaries. London, Heinemann educational Books, Ltd, 144p.

Miranda, L. B. de; Castro, M. B. de \& Kjerfve, B. 2002. Princípios de oceanografia física de estuários. São Paulo, EDUSP. 414p.

Moens, T. \& Vincx, M. 1997. Observations on the feeding ecology of estuarine nematodes. J. mar. Biol. Ass. U.K., 77:211-227.

Montagna, P. A. \& Yoon, W. B. 1991. The effect of fresh water inflow on meiofaunal consumption of sediment bacteria and microphytobenthos in San Antonio Bay, Texas, USA. Estuar. Coast. Shelf Sci., 33:529-547.

Netto, S. A. \& Lana P. C. 1996. Benthic macrofauna of Spartina alterniflora marshes and nearby unvegetated tidal flats of Paranaguá Bay (SE Brazil). Nerítica, 10:4156

Netto, S. A. \& Gallucci, F. 2003. Meiofauna and macrofauna communities in a mangrove from the Island of Santa Catarina, South Brazil. Hydrobiologia, 505:159-170.

Nybakken, J. W. 2001. Marine Biology: an ecological approach, $5^{\text {th }}$. ed. San Francisco, Benjamin Cummings. $516 \mathrm{p}$.

Ozório, C. P.; Bemvenuti, C. E. \& Rosa, L. C. 1999. Comparação da meiofauna em dois ambientes estuarinos da Lagoa dos Patos, RS. Acta Limnol. Brasil., 11(2):2939.

Pfannkuche, O. \& Thiel, H. 1988. Sample processing. In: Higgins R. P. \& Thiel, H., eds. Introduction to the study of meiofauna. Washington D. C., Smithsonian Institute Press. p. 134-145.

Plante-Cuny, M. R. 1978. Pigments photosynthétiques et production primaire des fonds meubles néritiques d' une région tropicale (Nosy-Bé, Madagascar). Trav. Doc. O.R.S.T.O.M., 96:1-359.

Riaux-Gobin, C. \& Bourgoin, P. 2002. Microphytobenthos biomass at Kerguelen's Land (Subantarctic Indian Ocean): repartition and variability during austral summers, J. Mar. Syst., 32:295-306.

Riaux-Gobin, C.; Dinet, A.; Dugué, G.; Vétion, G.; Maria, E. \& Grémare, A. 2004. Phytodetritus at sediment-water interface, NW Mediterranean Basin: spatial repartition, living cell signatures, meiofaunal relationships. Sci. Mar., 68:7-21.

Rosa, J. S. \& Bemvenuti, C. E. 2005. Effects of the Burrowing Crab Chasmagnathus granulate (Dana) on Meiofauna of Estuarine Intertidal Habitats of Patos Lagoon, Southern Brazil. Brazil. Arch. Biol. Techn., 48(2):267-274.

Rosa-Filho, J. S. \& Bemvenuti, C. E. 1998. Caracterización de las comunidades macrobentónicas de fondos blandos en regiones estuarinas de Rio Grande do Sul (Brasil). Thalassas, 14:43-56. 
Santos, P. J. P.; Castel, J. \& Souza-Santos, L. P. 1995. Microphytobenthic patches and their influence on meiofaunal distribution. Cah. Biol. Mar., 36(2):133-139.

SDM, I. P. 1997. Avaliação físico-química do sistema lagunar sul catarinense. Relatório Técnico SDM/UNISUL, Tubarão.

Seeliger, U. \& Kjerfve, B. 2001. eds. Coastal Marine Ecosystems of Latin America. Ecological Studies, vol. 144. 352p

Seuront, L. \& Spilmont, N. 2002. Self-organized criticality in intertidal microphytobenthos patch patterns. Physica, 313:513-539.

Soetaert, K.; Vincx, M.; Wittoeck, J. \& Tulkens, M. 1995. Meiobenthic distribution and nematode community structure in five European estuaries. Hydrobiologia, 311:185-206.

Sokal, R. R. \& Rohlf, F. J. 1997. Biometry: the principles and practice of statistics in biological research. $3^{\text {th }}$. New York, Freeman. 887p.

Somerfield, P. J. \& Warwick, R. M. 1996. Meiofauna in marine pollution programmes. A laboratory manual. MAFF, Directorate of Fisheries Research, Lowestoft. $71 \mathrm{p}$.

Somerfield, P. J.; Fonsêca-Genevois, V. G.; Rodrigues, A. C. L.; Castro, F. J. V. \& Santos, G. A. P. 2003. Factors affecting meiofaunal community structure in the Pina Basin, an urbanized embayment on the coast of Pernambuco, Brazil. J. mar. biol. Ass. U.K., 83:12091213.
Sousa, E. C. P. M. 1983. Primary production of the benthic microflora living on an intertidal flat in the Santos estuarine system $\left(24^{\circ} \mathrm{S}, 46^{\circ} \mathrm{W}\right)$, São Paulo, Brazil. Bolm Inst. oceanog., S Paulo, 32:177-186.

Sousa, E. C. P. M. \& David, C. J. 1995. Variação diária dos pigmentos fotossintetizantes do microfitobentos da praia de Aparecida, Santos (2358'48'S-46¹9'00’W), São Paulo, Brasil. Rev. Brasil. Biol., 56:147-154.

Tietjen, H. J. 1991. Ecology of free-living nematodes from the continental shelf of the central Great Barrier Reef province. Estuar. coastal Shelf. Sci., 32:421-438.

Warwick, R. M. 1971. Nematode associations in the Exe estuary. J. Mar. Biol. Ass. U.K., 51:439-454.

Warwick, R. M. 1984. Species size distributions in marine benthic communities. Oecologia, 61:32-41.

Wieser, W. 1953. Die Beziehung zwishen Mundhöhlengestalt, Ernährungsweise und Vorkommen bei freilebenden marine Nematoden - eine ökologischmorphologische Studie. Ark. Zool., 4:439-483.

(Manuscript received 10 March 2005; revised 25 July 2005; accepted 30 January 2006) 